\title{
The Existence of Wasathiyyah Islam in Madura (An analysis of Urban Society's Acceptance of Islamic Content on Social Media)
}

\author{
Moh. Zahid \\ (Sharia Faculty of IAIN Madura, Jln. Panglegur Km. 04 Pamekasan, \\ Email: z4hid.4lfawari@gmail.com) \\ Moh. Hasan \\ (Sharia Faculty of IAIN Madura, Jln. Panglegur Km. 04 Pamekasan, \\ Email:hm.hasan59@yahoo.com)
}

\begin{abstract}
:
The spreading Islamic content through Whatsapp as one of popular social media platforms which no longer reflects moderate (wasatiyyah) Islamic teaching has began to appear. It ranges from the content of Islamic teaching, the pattern of movement, response on contemporary life, to discussion on political system and discourses on nation-state. In responding to the Islamic contents implying radicalism, terrorism and ambition to change the form of state from republic into khilâfah based system, most of Maduresse urban people reject it. However, they still rely on the content spreaded through social media in understanding Islam. This dynamics could possibly influence people and lead them to either right or left extreme points out of the frame of moderate Islam taught by Rasulullah pbuh and classically recognized scholars ('ulamâ' salaf al-shâlih). Therefore, it is urgent to formulate a preaching strategy with the good content to provide people access on balanced information so they could be selective in understanding Islamic teaching.
\end{abstract}

\section{Keywords:}

Wasathiyyah, Islam in Madura, Islamic Content on Social Media

\begin{abstract}
Abstrak:
Penyebaran konten keislaman melalui media sosial (WhatsApp) yang tidak lagi mencerminkan wasathiyyat al-Islâm (moderasi ajaran Islam) mulai bermunculan baik materi keislaman, pola gerakan, penyikapan terhadap kondisi kekinian, bahkan perbincangan sistem politik dan kehidupan bernegara. Dalam menyikapi konten keislaman yang mengarah pada paham radikalisme, terorisme, dan gagasan mengubah sistem bernegara NKRI dengan konsep khilafah, mayoritas
\end{abstract}


masyarakat perkotaan di Madura menolaknya. Namun demikian terhadap konten materi keislaman yang disebarkan melalui media sosial, sejumlah kalangan sudah menjadikannya sebagai pijakan dalam memahami Islam. Dinamika ini dapat mempengaruhi masyarakat pada sikap ektrem kanan atau ekstrem kiri, yang keluar dari bingkai Islam wasathiyyah sebagaimana yang diajarkan oleh Rasulullah dan Para Ulama Salafus Shâlih. Oleh karena itu perlu strategi dakwah dengan materi yang tepat agar masyarakat mendapatkan informasi yang berimbang sehingga bisa selektif dalam memahami ajaran Islam.

Kata Kunci:

Wasathiyyah, Islam di Madura, Konten Keislaman di Media Sosial

\section{Introduction}

The development of society in terms of communication has been started from the era of writing, printed media, telecommunication media, to interactive communication media. ${ }^{1}$ Various information technology media have been developed to produce information that is relevant, accurate and timely. ${ }^{2}$ Information media has become an extension of the human senses. ${ }^{3}$ The phenomenon of the information media development has made people "depend on" the information technology. This can certainly bring positive and negative impacts. According to McLuhan, technology will restore humanity to become one tribe again, from a separate nation state becomes a "global-village".4 Rulli Nasrullah states that the rapid development of the media supported by the internet has brought the effects of the emergence of citizen journalism.

"The advancement of the internet technology, coupled with the characteristics of new media, has caused the phenomenon of freedom of speech or virtual public space (virtual sphere) to develop more rapidly.

\footnotetext{
1 Burhan Bungin, Sosiologi Komunikasi: Teori, Paradigma, dan Diskursus Teknologi Komunikasi di Masyarakat (Jakarta: Prenada Media Group, 2008), 11

2 Kumanto Sunarto, Pengantar Sosiologi, (Jakarta: Lembaga Penerbit Fakultas Ekonomi UI, 2004), 26.

3 Jalaluddin Rakhmat, Psikologi Komunikasi, (Bandung: Rosda, 2008), 220

4 Werner J. Severin - James W. Tankard, Teori Komunikasi, (Jakarta: Kencana, 2007), hlm. 336. See also Rulli Nasrullah, Komunikasi Antarbudaya di Era Budaya Siber, (Jakarta: Kencana, 2012), 140
} 
For example through the phenomenon of citizen journalism. This phenomenon is used by residents not only to produce and consume information, but also to get the attention of traditional media. Borrowing a perspective used by Deuze in his article "the future of citizen journalism" that the rise of the phenomenon of citizen journalism can be approached using economic perspectives, public perspectives, and cultural perspectives. These three perspectives are referred to by Deuzed as "a framework of convergence culture". 5

The phenomenon of citizen journalism is the movement of information dissemination carried out by citizens, which also offers media business opportunities with or without spending money at all because the content is fully filled by citizens. In a public perspective, citizen journalism provides not only an opportunity to involve the public in producing news, but also an alternative source of information which has been dominated by traditional media companies. public becomes a source of information that can supply content without editing processes like editorial mechanism, so that it can give a genuine touch in expressing opinions or cases according to their own perspective and expressions. Citizen journalism is a phenomenon that brings change to culture. Starting from the culture of accessing media of information, the culture of interacting, to selfdisclosure or self-image. ${ }^{6}$

The phenomenon of citizen journalism develops together with social media networks. Social media is an online media, in which users are able to easily participate, share and create contents including blogs, social networks, forums and virtual world. Blogs and social networks are the most common forms of social media used by people

\footnotetext{
5 Ibid., 145-148.

6 This is when it is compared with television as a media that instantly provides information to the public. Television has transformed. It is not only for entertainment and information. Jean Baudrillard describes television by presenting a theory about hyperreal world (false reality) and simulation, namely a concept refers to the state of virtual (virtual) or artificial culture in the era of mass communication and mass consumption. Jean Baudrillard states, television media is able to display simulations or models that are so intensely fulfilling the space of social life, so that blurring the boundary between the image and the fact, in other words, the media shapes reality, and that reality is often false, without meaning and context. Rulli Nasrullah, Komunikasi Antarbudaya di Era Budaya Siber, (Jakarta: Kencana, 2012), 150
} 
throughout the world. ${ }^{7}$ Social media is used to socialize with each other and is done online that allows humans to interact without being limited by space and time. ${ }^{8}$

Delivery of Islamic content by utilizing information technology as a medium is very important and effective. Speaking of $d a^{\prime} w a h$, the Quran states that it can be interpreted as a command to call humanity into the path of God with wisdom and good lessons with various methods and approaches (Q.S al-Nahl 16: 125). This verse means that it is obliged to invite people to the way of God with good wisdom and advice, so that they leave taghout (devil) and have faith in Allah (Q.S Ali Imran 3: 104).

Previously, the delivery of Islamic content was often synonymous with teaching or khutbah (sermon). ${ }^{9}$ Accordingly, utilizing social media for $d a^{\prime}$ wah could have a massive impact that can target all groups of people. Community acceptance of Islamic content

7 Wikipedia. Media Sosial, retrieved 03/10/2017 from http://id. wikipedia. org/wiki/Media_sosial

8 Rafi Saumi Rustian. Apa itu Media Sosial, retrieved 03/10/2017 from http://www. unpas. ac. id/apa-itu-sosial-media/. According to him, social media can be categorized into several major categories, namely:

a. Social Networks, social media for socialization and interaction (Facebook, myspace, hi5, Linked in, bebo, etc.)

b. Discuss, social media which facilitates a group of people to chat and discussion (google talk, yahoo! M, skype, etc.)

c. Share, social media which facilitates us to share files, videos, music, etc. (youtube, slideshare, feedback, flickr, crowdstorm, etc)

d. Publish, (wordpredss, wikipedia, blog, wikia, digg, etc.)

e. Social game, social media in the form of games that can be played together (koongregate, doof, pogo, cafe. com, etc.)

f. $\mathrm{MMO}$ (kartrider, warcraft, neopets, conan, etc.)

g. Virtual worlds (habbo, imvu, starday, etc.)

h. Livecast (y! Live, blog tv, justin tv, listream tv, livecastr, etc.)

i. Livestream (socialize, froendsfreed, socialthings!, etc.)

j. Micro blog (twitter, plurk, pownce, twirxr, plazes, tweetpeek, etc.)

${ }^{9}$ In a narrow sense and in etymological meaning, it comes from Arabic, which means a calling as stated in the Alqu'an, Yunus verse 25. Broadly speaking Islamic da'wah is the effort of faithful people to influence and invite people in wise a way to follow the teachings of Islam in all aspects of life for their benefit and happiness in the world and the hereafter. Rodani, H. Komunikasi dan Dakwah. (Jakarta: Azhikra, 2010), Vol 1: 1 
accessed through social media often occurs without critiques in the viewpoint of wasathiyyah Islam.

The term wasathiyyah refers to a commendable condition which keeps a person from the tendency towards two extreme attitudes; exaggeration (ifrâth) and the attitude of muqashshir which reduces something which is limited by Allah. This attitude has made Moslems as moderate people; moderate in all matters, both religious and social affairs.

Wasathiyyah (moderate understanding) is one of the characteristics of Islam that is not shared by other religions. Moderate understanding calls for tolerant dakwah of Islam, opposing all forms of liberal and radical thinking. In this context, liberalism refers to understanding Islam with passion and pure logic standards that tend to seek unscientific justification, while radical means interpreting Islam in textual level which might eliminate the flexibility of its teachings, so that it seems to be rigid and unable to read the reality of life. The attitude of wasathiyyah to Islam is an attitude of resistance to extremism in the form of tyranny and falsehood. it is nothing but a reflection of the true nature of a human who is not polluted by negative influences. ${ }^{10}$

Therefore, a study that examines the shift in the understanding and acceptance of society towards Islamic content characterized by wasathiyyah attitude is very important, especially in Madura which is identical to Nahdlatul Ulama (NU). NU positions itself as an Islamic and social organization that rests on the teachings of the Ahlus Sunnah wal Jamaah (ASWAJA) with moderate religious attitude (wasathiyah). For this reason, this research untitled "The existence of Wasathiyyah Islam in Madura (An Analysis of the Acceptance of Urban Communities on Islamic Content through Social Media)" is conducted. In this paper, the social media refers only to WathsApp.

\section{Theoretical basis}

10. Ibnu 'Asyur, Ushûl al-Nizhâm al-Ijtimâ̂̂ fi al-Islâm, 1979 :17. Read also Afrizal Nur dan Mukhlis, "Konsep Wasathiyyah dalam Al-Qur'an (Studi Komparatif antara Tafsir al-Tahrîr wa al-Tanwîr dan Aisar At-Tafâsîr)" in An-Nur, Vol. 4 No. 2, 2015 (ejournal. uin-suska. ac. id) 
The word wasathiyyah derives from the word "wasathan". AlAsfahaniy defines "wasathan" with "sawâ'un" which is the middle between two boundaries, or justice, the middle or the standard or the mediocre, wasathan also means avoiding of being ifrâth and tafrith. The word wasath with its various derivatives is mentioned 3 times in the Qur'an, namely in al-Baqarah verse 143 and 238, al-Qalam verse 48.11 Similarly, the same meaning can also be found in $M u^{\prime} j a m$ al-Wasith namely "adulan" and "khiyâran" which mean simple and selected. ${ }^{12}$

Ibnu 'Asyur defines the word "wasath" in two meanings. First, in the etymological definition, the word wasath means something that is in the middle, or something that has two tips with comparable size. Second, according to the terminology, the meaning of wasath is Islamic values built on right and mid mindset, not being excessive in certain respects. The meaning of "ummatan wasathan" in the Q.S al-Baqarah 2: 143 is a just and choosen people. That is to say, Moslems are the most perfect religious people, the best in morality, and the most excellent in their deeds. Allah has bestowed Moslems knowledge, gentleness, justice, and goodness that are not given to other people. Therefore, they become "ummatan wasathan", perfect and just people who become witness of all humans in the Day of Judgment.13 The same meaning is also stated by al-Jazâ'irî in his interpretation book, he interprets the word "ummatan wasathan" in the al-Qur'an as a just, best and chosen people who has a mission of straightening.

With regard to the meaning that Moslems is as choosen and straight people, al-Jazâ' irî states when he interprets the Quran; as we give guidance to you by settling the main qibla, namely the Ka'bah, which was the qiblah of the prophet Ibrahim, therefore, we also make you the best people who is always straightening, so that you deserve to be a witness of human actions, namely other people on the Day of Judgment if they deny the message conveyed, while on the contrary, they cannot be witnesses for you, because the Prophet who acts as the

\footnotetext{
11al-Raghib al-Asfahanî, Mufradât Alfâdz al-Qur'ân, (Bairût: Dar al-Qalam, 2009), 869.

12 Dzul Faqqar 'Ali, Mu'jam al-Wasith, (Kairo: ZIB, 1973), 1031.

13 Muhammad at-Thahir Ibnu 'Âsyûr, At-Tahrîr wa al-Tanwîr (Tunis: ad-Dar Tunisiyyah, 1984), 17-18.
} 
witness for yourself. This is the form of glorification and the gift of God to you. ${ }^{14}$

From the explanation above, it can be seen that there is a similar point between the meaning of ummatan wasathan proposed by Ibnu 'Asyur and what proposed by al-Jazâ'iri. There is no conflicting meaning with each other. Therefore, it can be concluded that Wasathiyyah is a commendable condition that keeps one from the tendency towards two extreme attitudes; exaggeration (ifrâth) and the attitude of muqashshir which reduces something which is constrained by Allah. The attitude of wasathiyyah of Moslems is a special gift from Allah. When they consistently carry out the teachings of Allah, at that time they become the best and choosen people. This attitude makes Moslems become moderate people; moderate in all matters, whether religious or social affairs in this life.

Wasathiyyah (moderate understanding) is one of the characteristics of Islam that is not shared by other religions. Moderate understanding calls for tolerant da wah of Islam, opposing all forms of liberal and radical thinking. In this context, liberalism refers to understanding Islam with passion and pure logic standards that tend to seek unscientific justification, while radical means interpreting Islam in textual level which might eliminate the flexibility of its teachings, so that it seems to be rigid and unable to read the reality of life. ${ }^{15}$

In the history of Islamic scholarship, the terms 'moderate Islam', 'Arab Islam', Liberal Islam, progressive Islam or 'Nusantara Islam' are not known, because Islam is a divine religion that Allah reveals to the Prophet Muhammad to complete the mission of peace universally. It is really inappropriate to discredit Islam - as a religion through partial terms that can reduce the majesty of the meaning of Islam itself. ${ }^{16}$ The same thing is also stated by Al-Jazâ'iri, he adds that Islam is the universal religion of choice, all its teachings must be obeyed and performed. Every Moslem must be able to prove the majesty of the laws and teachings of Islam in amongst non-Moslem

14 al-Jazâ'iri, Jâbir, Aisar At-Tafâsîr li Kalâm al-'Aliy al-Kabîr, Vol. 1, (Jeddah: Racem Advertising, 1990), 125-126.

${ }^{15}$ Muhammad at-Thahir Ibnu 'Âsyûr, Ushûl an-Nizhâm al-Ijtimấ̂ fi al-Islâm, (Tunis: AsSharikah at-Tûnisiyyah li at-Tauzî',1979), 17.

16 Ibnu 'Âsyûr, At-Tahrîr wa al-Tanwîr, 189. 
societies, so that they are able to distinguish between the call of truth and the whisper of falsehood. ${ }^{17}$

Moslems must be careful in the 'war of terms' raised by Western intellectuals. Lately, the term "moderate" has a tendency to raise a certain group and bring down other groups. This word is usually used as antonym of fundamentalism and absolutism. In fact, unwittingly, the term wasathiyyah is often used to refer to those who act and think liberally in religion. While those who consistently perform Islamic teachings are often considered as a non-moderate group.

The group called 'moderate Islam' is considered as 'friendly Islam' and can be a Western partner. On the contrary, according to the West, what is called 'radical Islam' or 'extremist' is Islam which rejects the ideology of Secular Capitalism, anti-democracy, and does not want to compromise with the West. In other words, 'radical Islam' is a Moslem who is faithful to the way of life and values of Islam, and adheres to the ideology and Islamic law. Radical people are those who want to implement Islam compeletely. For the West, this Islamic group is not only considered as 'extreme' and anti-Western Islam, but also a threat to their civilization. ${ }^{18}$

The division of islamic groups into moderate and radical groups is intended as a form of clarification to the international community that Islamic $d a^{\prime} w a h$ is done very friendly, and tolerant. Moderate Moslems try to reassert true Islamic values, without coercion or violence in the name of religion (schools of thought, etc.). Thus, it can be understood that Islam is only one; cannot be divided, while Moslems are creative and innovative people, the majority of them are moderate groups based on the Qur'an, while the minority of them is divided; there are moderate groups of the West version, and there are anti moderate groups who are very intolerant against differences of opinion (beliefs, etc.).

In response to the development of views and the movement of intolerant, rigid group and those who are easily call others as infidel (takfîri), it is important to formulate the characteristics of ummatan

\footnotetext{
17 Al-Jazâ'iri, Aisar At-Tafâsîr ..., 297.

18 Muhammad Rizieq, Hancurkan Liberalisme Tegakkan Syariat Islam, South Jakarta: Suara Islam, 2011), 46.
} 
wasathan to strike for moderate values of Islamic teachings in religious, social, national and state life. Moderate attitude is a manifestation of Islamic teachings which is rahmatan li al-âlamîn; mercy for all the universe. Moderate attitudes need to be fought for the birth of the best people (khairu ummah).

The moderation of Islam requires a Moslem to be able to respond to differences, in the sense that what has been a difference between each religion or sects does not need to be equated, and what has been the same between each religion or sects should not be differentiated or contradicted. Differences are part of the nature's law (sunnatullah) that cannot be changed and abolished. This has become God's destiny, it is the humans who have to learn how to realize themselves. Islam teaches people how to call others to the path of Allah the Almighty, in a wise way, good examples and polite dialogue (al-Nahl 16: 125), without hostility and hatred because of differences.

\section{Research methods}

This study applies qualitative ${ }^{19}$ and descriptive, ${ }^{20}$ and phenomenological approach. A qualitative approach is an approach that attempts to understand subjective meanings of the subjects being studied. Therefore, the researcher should conducts intensive interaction or communication with the subjects being studied, and be able to understand and develop categories, patterns and analysis of social processes that occur in the community. ${ }^{21}$

The reasons why this study applies qualitative approach are; First, the phenomena to be examined are dynamic social phenomena. Second, the subject matter (material) in this study is related to the process of an action shown by the phenomena which take the form of thoughts, speeches and actions taken by the community. According to Creswell, the main concern of qualitative research is related to motivation and ritual processes. The third reason is that the events or

${ }^{19}$ Lexy Moleong, Metodologi Penelitian Kualitatif (Bandung: Remaja Rosdakarya, 1990) 3.

20 Arief Furchan, Pengantar Metode Penelitian Kualitatif (Surabaya: Usaha Nasional, 1992) 21.

${ }^{21}$ John Creswell, W, Research Design; Qualitative \& Quantitative Approach,(California; Sage Publications, 1994), 157-159. 
dynamic social processes to be investigated, can only be well understood if the data and information are fully presented, by developing relevant categories, including interpretative analysis.

The phenomenological approach applied in this qualitative research refers to the interpretive effort towards human understanding in which, to understand the phenomena being studied, the researcher interacts with other people. To sharpen the analysis, the researcher also explores various literature and documents relating to the concept of Wasathiyyah Islam and the religious model of the Madurese community.

\section{Discussion}

\section{Islamic Contents on Social Media that Draw Attention of Urban Communities in Madura.}

Most of the respondents use WhatsApp (WA) as a media to get information, means of friendship and communication, reading things of interest. The rests just skip it, in other terms they are often called as silent readers. However, there are also respondents who use WhatsApp for wider purposes, they intensively uses WA as a means to explore their thought and ideas in healthy discussions regarding current issues.

Most of the discussion topics that are of interest are Islamic studies, including maw'izhah hasanah (good advice), study of the laws of worship, and Islamic history. In fact, information exchange through WA covers broader topics, it includes political news, advertisement, news, whose validity is hard to examine, and reunion.

A controversy in many religious issues disseminated through WA is not on a new issue, but on issues that had long been debated amongst Islamic scholars. Various religious issues referred to, such as the issue of intentions (read: recite intentions), qunût, commemoration of the Birthday of the Prophet Muhammad, nishf Sya'bân tradition and visisting graves tradition before Ramadan, and the number of Tarâwîh prayers. It is still in the category of wasathiyyah Islam when the dissemination of the controversy on the religious issues still provides space for respecting different opinions.

Controversies on religious issues that can be justified in the perspective of wasathiyyah of Islam are those which are based on 
legitimate arguments, namely based on the Quran, Hadith, Ijmấ and Qiyas. controversies on issues which are ijtihâdî in nature (based on personal examination of an issue) are unavoidable, and therefore the appreciation of a diversity cannot be avoided.

Islam as a religion includes two kinds of teachings, the first is the teachings that are absolute, universal and permanent as stated in the Qur'an and mutawatir Hadith and the second is the teachings produced through the process of ijtihâd, therefore they are relative, not universal and not permanent, can change and be changed. ${ }^{22}$ Amongst Islamic legal theorists there is a dichotomy between the definte (qat' $\imath$ ) text (the first group of teachings) and the indefinite (dzannî) text (the second group of teachings). In fact, there is more indefinite law than the definite one. The teachings of Islam that are not absolute and temporary have given rise to the treasures of Moslem intellectuals in various fields of science, such as interpretations, hadiths, philosophy, theology, and law.

The Islamic law rooted in the definite text constitutes the scope of ijtihâd, which produces what is called figh. Islamic law in this sense provides the epistemological possibility of law that each region inhabited by Moslems can apply the law differently. This can be seen in the trends of the legal system in Moslem countries today. This is not only caused by differences in the political system adopted, but also by historical, sociological and cultural factors of each Moslem country. ${ }^{23}$

As discussed in the science of ushîl figh, ijtihâd is a means for making changes and reforming the law. Ijtihâd can also be understood as a method for answering legal issues, whether they are stated in the texts or not. ${ }^{24}$ Thus, ijtihâd in Islam, as stated by Iqbal, is "the principle of movement", encouraging the progress of Moslems. ${ }^{25}$ In other words, ijtihâd is the key to the dynamics of Islamic teachings including its legal field.

\footnotetext{
22 Harun Nasution, "Ijtihad Sumber Ketiga Ajaran Islam", In Ijtihâd dalam Sorotan , ed. Haidar Bagir (Bandung: Mizan, 1988), 112.

23 Ahmad, Dimensi, 20.

${ }^{24}$ Fathurrahman Djamil, Metode Ijtihâd Majlis Tarjih Muhammadiyah (Jakarta: Logos Publishing House, 1995), 12.

25 Ibid., 11.
} 
One of examples of Islamic content which clearly states that people who read qunut at the Fajr prayer constitutes bid'ah, as exposed in the data collected:

"They read qunut let them read it, we read praise to Allah. DO NOT FOLLOW THEIR QUNUT. However, if the imam sujud (performs his bow) we are obliged to follow him, because we are the follower of the Imam, we must not disobey him, BUT IF THE IMAM DOES BID'AH, WE MUSTNOT FOLLOW HIM. IS IT CLEARRRR?"26

The expression of such Islamic teachings content which denies different opinions amongst Islamic scholars as mentioned above is the content of social media that does not reflect the Wasathiyyah Islam.

\section{The Acceptance of Urban Communities in Madura to Islamic Content on Social Media.}

In its development, the internet changes from the tool for entertainment into a primary need for most people. In the past, when the writer was in elementary school, he was fed with adages such as: books are the window of the world, or reading and language are the key to science, but the millennial generation knows more adages such as; the internet is the solution to every problem, or the internet data balance is a cure for all diseases. This is not excessive because the role of the internet enable the users to access and find information throughout the world quickly and easily.

Social media with all its various types becomes a logical consequence of the presence of the internet. The creators of social media seem to understand human nature that humans are created with the basic nature of interacting with each other. In the view of Islam, Allah implies that meaning with His word which reads khalaq al-insân min 'alaq (created man from a clinging substance).

The verse literally means that God created human beings from a blood clot, but in exoteric interpretation it can be interpreted as something that hangs, namely what is called by embryologists as zygote, namely the meeting between sperm cells and the ovum which is 'hanging' on the uterine wall. Furthermore, esoteric interpretation reveals that the use of the word 'alaq shows that humans are interdepent with each other, they cannot live alone. Aristotle calls it as

\footnotetext{
${ }^{26}$ Reread the previous data
} 
zoon politicon (social creature), Adam Smith uses the term homo homini socius (humans are friends for others), and Ibn Khaldun says that alinsân madanî bi al-thab'.

The Whatsapp (WA) is a popular social media application. It enable us to can communicate with anyone with the telephone number as a link. In the context of scientific studies, therea are lot people who use this application to discuss and exchange ideas, as well as for other aspects of life such as purchase and sale, organization, frienship and $d a^{\prime}$ wah.

Despite initially being skeptical of the internet, Syrian Islamic scholar, Sheikh Muhammad Sa'id Ramadhan al-Buthi says:

"It turns out that the internet network that almost engulfs all corners of the world is a vast land which has scattered podiums that voice the interests of Islam, by introducing, inviting (da'wah), defending and solving various problems."

Da'wah through the internet, especially using the WA application, is considered effective and potential for several reasons, including being able to penetrate the boundaries of space and time instantly with relatively affordable energy. With a dramatic increase of the internet users every year, it means that it also affects the number of those who absorb of missionary mission (da'wah).

The urban WA group consists of various circles with different backgrounds, from bureaucrats, community leaders, civil servants, honorary teachers, military, to police. They also come from different educational backgrounds; graduates of Islamic boarding schools, the general public, undergraduate, master and doctoral degrees.

This different background results in different content posted. The responses to content also vary. There are those who consistently respond to every content even though it is only with the thumb icon, like, or smile icon, some respond at certain times, especially when it is related to a sensational news. However, in general, most of them are silent readers. When observed, there seems to be some contents that could easily stimulate responses from WA members. They are the content related to Jokowi's policies (such as the increase of electricity tariffs or the fuel price), the phenomenon of moral decadence (such as when there was a dance at the Koran sermon show in an area in Sampang), and issues related to blasphemy of Islam and ulema (such 
as the Sukmawati case and criminalization of Habib Riziq). It is sometimes much easier to stimulate response with this kind of topic.

In response to the topics of general and Islamic studies, it can be said that the responses from WA group members being studied, are quite moderate, they are neither extreme right nor left, there is no truth claim. However, it is still necessary to question the motives behind this moderate attitude; is it really instinctively moderate? Does silent means agreeing because of reluctant or feeling uncomfortable as respected senior figures around, or due to awareness of different views and being a minority group.

Even if comments that can be categorized as truth claim, sarcastic, by accusing a prominet figure has been quilty, are found, it could be said that it is done by one of the people who has the following criteria; the elder kyai and or someone who is named so that no one dares to refute, lay or pesantren people who do not live in a bureaucratic circle, someone who does not have a tertiary education or a master's degree; Such as the wrong verdict and Accusing Jokowi a part of PKI (Indonesia Comunist Party) originating from abusive news links or well-known media but without further clarification, a heretical verdict against Ust. Abdul Somad because of his statements that are considered different sourced from a video that has been cut, without clarification using the whole video.

This research reveals that Islamic content on social media that draw a lot of attention from urban communities in Madura is very diverse. The content related to Islamic teachings varies. If viewed from the perspective of wasathiyyah Islam, the content can be divided into two types; 1) there are contents that still respect the differences in understanding and practicing islamic teachings amongst Moslem internally, and 2) there are contents that show the opposite, which tend to feel the most correct person in understanding Islamic teachings.

The great numbers of Islamic contents in social media, are used by the WA users as a means to increase knowledge about the guidance of Islamic teachings and encourage them to act accordingly. In the context of Islamic material, the majority of $W A$ users remain firmly adhering to the teachings of ahlus sunnah wal jamaah, especially those brought by the Nahdlatul Ulama organization. However, there are some communities that are affected by new understandings that 
tend to spread new Islamic understandings claimed as the path that are the most fit the teachings of the Prophet. This is stated as the most correct ones (truth claim).

From the perspective of wasathiyyah, urban communities in four districts in Madura can still be considered good. Urban communities are still be able to keep from the tendency of coming into two extreme attitudes; exaggeration (ifrâth) and muqashshir attitude which reduces something that is already constrained by Allah. The wasathiyyah attitude of Moslems is a special gift from Allah. When they consistently carry out the teachings of Allah, they become the best and choosen people. This attitude has made Moslems as moderate people; moderate in all matters, whether religious affairs or social affairs in the world.

Wasathiyyah (view) is one of the characteristics of Islam that is not shared by other religions. Moderate understanding calls for tolerant da'wah of Islam, opposing all forms of liberal and radical thinking. In this context, liberalism refers to understanding Islam with lust and pure logic standards that tend to seek unscientific justification, while radical means interpreting Islam in textual level which might eliminate the flexibility of its teachings, so that it seems to be rigid and unable to read the reality of life. The attitude of wasathiyyah Islam is an attitude of resistance to extremism in the form of tyranny and falsehood. it is nothing but a reflection of the true nature of human who has not been polluted by negative influences.

This can be seen from discussions in some WA groups and the results of field interviews, which show that:

1. The majority of the people support the notion that Islamic values should present in the society without radicalism in practicing the religion. No one support or justify the idea that radical actions or even a terror action is a part of the practice of Islamic teachings.

2. The community considers radicalism and terrorism as not the teachings of Islam. To prevent them, eduction especially character education must be built as a foundation of the community life.

3. The community is accustomed to different opinion, thus their attitudes toward the diversity of views and practices of Islam are based on tolerant views. 
4. Lawsuits against parties that are deemed to commit blasphemy are done through legal process so that they keep holding the principle of wasathiyyah Islam.

5. Although the concept of khilafah is very aggressively campaigned, the majority of urban people see that the form of th state of Indonesia (NKRI) is the best choice.

\section{Islamic Content in Social Media Drawing the Attention of Urban} Communities in Madura in the Frame of Wasathiyyah Islam.

The attention of the urban community in Madura as shown above is still within the limits of wasathiyyah Islam. Technically, the understanding and practice of the religion of a moderate Moslem have the following characteristics:

1. Tawassuth (taking the middle way), namely understanding and practice that are neither ifrâth (excessive attitude in understanding and practicing the religion) nor tafrith (reducing religious teachings);

2. Tawâzun (balance), which is a balanced understanding and practice of religion which covers all aspects of life, both worldly life and life in the hereafter, which is firm in stating principles and be able to distinguish between inhiraf, (deviations), and ikhtilaf (differences);

3. I'tidâl (straight and firm), which is putting something in its place and implementing rights and fulfilling obligations proportionally;

4. Tasâmuh (tolerance), namely recognizing and respecting differences, both in religious aspects and various other aspects of life;

5. Musâwah (egalitarian), which is not being discriminatory to others due to differences in beliefs, traditions and the origin of a person

6. Syûra (deliberation), that is, every problem is resolved by deliberation to reach consensus with the principle of putting benefit above all;

7. Ishlâh (reform), which prioritizes reformative principles to achieve a better state that accommodates the changes and progress of the era based on the common good (mashlahah 'ammah) by adhering to the principle of al-muhafazhah 'ala alqadimi al-shalih wa al-akhdzu bi al-jadidi al-ashlah (preserving old 
traditions that are still relevant, and applying new things that are more relevant);

8. Aulawiyah (prioritizing the most important thing), namely the ability to identify more important things that must be prioritized to implement compared to those with lower interests;

9. Tathawwur wa Ibtikâr (dynamic and innovative), which is always open to make changes in accordance with the times and create new things for the benefit and progress of mankind;

10. Tahadldlur (civilized), which is upholding noble character, haracter, identity and integrity as khayr ummah (the best people) in humanity and civilization. It is not necessary to stay away from religion (atheism) in order to be a person who thinks and acts moderately, or not to blaspheme other people's beliefs. It is possible that this attitude often arises because of the influence of globalism and neolibralism. This kind of person often blaspheme other people's beliefs by claiming themselves to be the most righteous while others are heretical and infidels. This is the virus that is now destroying Moslem unity. This attitude is an extreme attitude in religion. ${ }^{27}$

The presence of contents that tend to be out of the frame of Wasathiyyah Islam does not necessarily affect urban society, especially in the realm of action. However, it is found that some of them start accepting the content because it is considered a way to view and practice the religion that is in accordance with the Sunnah. Therefore there needs to be a balance of information about the teachings of Islam that are more tolerant, be able to deal with a diversity of views, and accepting the fact of the diversity in the life of the nation and state.

In Indonesia, the emergence and growth of radical groups has also disturbed society. They have exploded a number of bombs in various major cities, especially in Jakarta and Bali. in response to this scholars, leaders of community, institutions and religious organizations are busy explaining that Islam has nothing to do with radical groups, radicalism, and especially terrorism.

\footnotetext{
27 Al-Amir Syukaib Arsulan, Limâzâ Ta'akhkhara al-Muslimûn? (Qatar: Wazâratu alTsaqâfah wa al-Funûn wa atTurâts, nd.), 53.
} 
This condition is made worse by the political situation that seems to divide the community into two large extreme groups. A number of parties then talk about the need to strengthen four pillars Pancasila, the 1945 Constitution, Bhinneka Tunggal Eka, and the state of republic of Indonesian (NKRI) - in the life of the nation so that Indonesia does not torn apart in the two extremes. For the majority of Moslems in Madura, the four pillars are final. The consensus of the founding fathers of the nation, who were mostly islamic scholars. The consensus can be achieved because they adhere to the understanding of wasathiyyah Islam, based on deliberations to reach agreement. Consensus means being able to accept and give.

In one of WA group "GUIP MANAG" there is one post that attach the "Original Text of Declaration of Nahdlatul Ulama (NU) on The Relationship Between Pancasila And Islam". The harmony of the religious community in Indonesia has attracted other countries. Indonesia becomes an example. As a Moslem-majority country - even the largest in the world -, the people of Indonesia are able to live harmoniously in a pluralistic society. They live in different tribes, religions, races and groups. Compare this with countries in the Middle East with the same religion and language, yet they continue to live in a conflict. That is why, no wonder when the President of Afghanistan and other parties there, as told by Joko Widodo, want to learn from Indonesia about the unity.

Even the prominent Sheikh of Al Azhar, Dr. Ahmad Thoyyib frankly praises Indonesia as a role model of the implementation of this moderation of Islam or wasathiyyah Islam. He has visited Indonesia three times. The last time was when he became the keynote speaker at the High Level Consultation of World Moslem Scholars on Wasathiyyah Islam (HLS-WMS) for three days (May 1-3) in Bogor. This event was also attended by More than 100 domestic and foreign Moslem scholars.

During the three days of discussion, the meeting of the world ulama has produced Bogor Message, a message from Bogor to the world. It has seven points, all of which are to reaffirm the meaning of wasathiyyah, namely, wasathiyyah means tawassuth: the straight middle path; not extreme right and left. Wasathiyyah also means i'tidal: acting proportionally, fairly and responsibly. Wasathiyyah also implies tasamuh, which is tolerant, recognizes and respects differences 
in all aspects of life. It also means sŷurâ: which is relying on consultation in solving problems through deliberation to reach consensus. Wasathiyyah also means islâh: engaging in reformative and constructive actions for the common good. It also means qudwah: inspiring lofty initiatives and leading to human welfare. Finally, wasathiyyah also means muwâthanah: acknowledging the nation state and respecting citizenship.

In this perspective, the researchers seek to authenticate ( $t a^{\prime}$ shîl) the issue of violence with religious nuances by calling it an act of "tatharruf", "tasyaddud" or "ghuluw ". Likewise, to straighten it out, if it is seen that religious understanding as one of the reasons, we are more likely to choose the enforcement of the principle of "wasathiyyah" in religious understanding and behavior. The mission of da'wah and tajdîd (reformation) is to move and present Islam as a teaching that develops moderate attitudes, builds peace, values pluralism, respects the dignity of men and women, educates the life of the nation, upholds noble character, and promotes a better human life. The Muhammadiyah's commitment shows a dynamic and progressive character of Islamic movement in responding to the challenges of the times, without having to lose the identity and of authentic reference of Islam.

In Arabic the word extreme is called "tatharruf", which means lexically as follows:

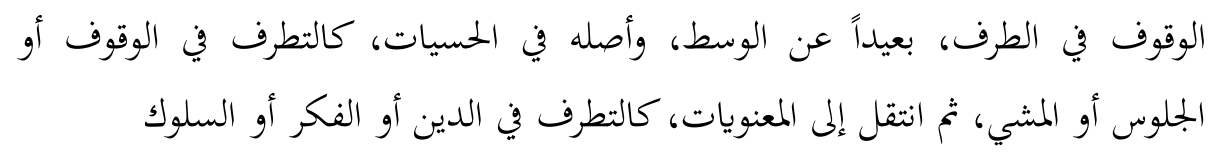

In the Qur'an, the word "tatharruf" is synonymous with the word ghuluw (overdo) as can be read in the word of God "do not overdo your religion". Observing the meaning of the word extreme, it is important to explain the questions put forward above by the writer and to put them proportionally so as not to obscure the essence the issues discussed.

Thus, the term "extreme Islam" is nothing more than a combination of two contradictory words as one says, "righteous corruptor", which is certainly unacceptable, especially it is associated with the politics of stigmatization carried out by certain Islamophobic forces. With regard to the fact that extremism and radicalism 
become a part of some Moslems, according to the writer, it is more appropriate to say that they are performing Islamic teachings in an extreme or radical manner.

There is a quite important question that should not be missed: why does the attitude and behavior of "tatharruf" or "ghuluw" occur? According to Yusuf al-Qaradlawi, extreme attitudes and behaviors performed by a small number of Moslems stem from the following points: the weakness of bashîrah regarding the essence of the din; dlâhirî oriented in understanding the texts; neglecting something important and should be prioritized; exaggerating attitude in prohibiting things; and, conceptually confusion or anxiety.

Nashir Abd Karim al-'Aql, a professor of theology at the University of Imam Muhammad Ibn Saud, Riyadl, adds the following to the cuases of extreme attitudes: ignorant about the science of syar'i and the lack of understanding of the din; the gap between the youth and the ulama, and competent authorities; inequality in contemporary $d a^{\prime} w a h$ methodology; poor intellectuality and analysis, and the lack of patience and wisdom; the desire to instantly come into being; tasyaddud fid din; the attitude of ta'alum and ghurur; excessive enthusiasm; and depraved media.

As a universal religion, islam is diametrically opposed to the attitudes and behavior of "tatharruf" or "ghuluw" " and various other similar terms. As a concrete step (action) to uphold the principle of wasathiyyah, first, it is necessary to reconstruct "Ikhilaf Jurisprudence"

Second, it is necessary to revitalize tasamuh (tolerance) in plural community. As a foundation for the life of our pluralistic nation in an atmosphere of co-existence and full tolerance (tasamuh), the researchers propose the following propositions:

1) As good Moslems we believe that every human being from the point of view of his creation (ontologically) has glory (karâmah), regardless of race, color, ethnicity, nation including religion, according to the word of Allah in the Quran, al-Isrâ '17: 70. So the glory rights as human beings created by Allah must be protected and maintained, except with the violations that have been determined in Islamic law.

2) Be appreciative and broad minded of the fact of diversity, because differences in beliefs and religion are something that is natural from God as stated in al-Maidah 5: 48). Therefore, it is not 
possible for a Moslem to intimidate, force, or even terrorize others in order to convert to Islam.

3) Understand that the command of $d a^{\prime} w a h$ in Islam which aims at the realization of transformation and change to goodness and truth, both at the personal and community level, should be done with persuasive and elegant communication, not indoctrination. It should also be understood that God does not burden us to be responsible for the sins of unbelievers or the heresy of those who are heretical. What is important is that we have preached, as the word of God in the Quran, al-Ankabût 29:18. Thus, a Moslem will live comfortably with openess and willingness.

4) God commands us to love justice; act proportionally, call for morality and forbids tyranny, even against polytheists. As the God says in the Quran, al-Maidah 5: 8.

5) In the context of interreligious dialogue, it should not be claimed that all religions are ture (pluralism), under any pretexts, including the theory of the transcendent unity of the Schoun religions which are further elaborated by Moslem thinkers, Nurcholish Madjid, with his pluralist inclusive ideas. It is because such ideas is a part of theological violence and terror (al-'unfu wa al-irhab al-'aqadî) which is actually opposed by all religions in the world.

6) Hold the attitude of trust and honesty in religion; not only in pure rituals, but also in matters that have the potential to confuse the teachings of religions such as Christmas celeberation and prayer together in the name of togetherness, nationality or local wisdom and so on. Tolerance does not mean willingness to attend rituals and worship of other religious communities. Thus, each believer would feel willing and no one feels disrespected, let alone harassed, just because the people hold their own belief.

7) Out of area of faith, it needs to remember that Islam teaches commitment of human brotherhood (al-muswh, not secular humanism) fairly and wisely in the form of cooperation in worldly affairs (mu'amalat dunyawiyah) without mixing up the teachings of religions. The historical facts of life of the Prophet and the people of Medina can become an example of true tolerance. It is not like the claim of religious pluralism that is oriented towards equating religions in the world and negates the 
unique characters to each of these religions. In addition to contradicting the Shari'a of Allah, this also ignores and defames human rights to believe in their religions.

8) Outside the area of faith, Islam teaches about the commitment of human brotherhood (al-musâwâh, not secular humanism) fairly and wisely in the form of cooperation in worldly affairs (mu'amalat dunyawiyah), Without mixing up the teachings of religions. The historical facts of life of the Prophet and the people of Medina can become an example of true tolerance. It is not like the claim of religious pluralism that is oriented towards equating religions in the world and negates the character that is unique to each of these religions. In addition to contradicting the Shari'a of Allah, this also ignores and defames human rights to believe in their religions.

\section{Conclusion}

From the findings and discussions described in the previous chapter, it can be summarized as follows:

1. Islamic contents on social media that draw attention of urban communities in Madura are very diverse; in the form of Islamic materials, movement patterns, attitudes towards the present condition in various aspects, and ideas about the life system of the nation and state.

2. The exposure to Islamic content as referred to in point 1 is addressed differently by urban communities in Madura. Some make it as simply information, discuss it in both sides, agreement and disagreement, while others make it as a basis for understanding Islam. Nevertheless, the majority of urban people refuse the notion of radicalism and terrorism including the idea of changing the system of the state with the concept of khilâfah.

3. From the perspective of wasathiyyah Islam, the majority of Islamic content on social media is still in the frame of moderate Islam. However, there are some Islamic contents on social media that draw the attention of urban communities in Madura which have shifted to the extreme right or left. The community is not easily influenced by various Islamic contents which are out of islamic context. 


\section{Bibliography}

Al-'Imâdî, Abû al-Su'ûd, Irshâd al-'Aql al-Salîm ilâ Mazâyâ al-Kitâb alKarîm, Vol. I (nd.)

Al-Amir Syukaib Arsulan, Limâzâ Ta'akhkhara al-Moslemûn? (Qatar: Wazâratu al-Tsaqâfah wa al-Funûn wa atTurâts,) (nd.).

Al-Asfahaniy, Al-Raghib, Mufradât Alfâdz al-Qur'ân, (Dar al-Qalam, Beirut, 2009).

al-Bukhârî, Abû 'Abd Allâh Muhammad ibn Ismâ'îl, Shahîh al-Bukhârî (Beirut: Dâr Ibn Kathîr, 2002)

Al-Fayrûz Abâdî, al-Muhîth, Vol. 1, 893 (Software Maktabah Shâmilah, Vol. II)

al-Jazâ'irî, Abû Bakar Jâbir, Aysar al-Tafâsîr li Kalâm al-'Alî al-Kabîr, Vol. I (Jeddah: Racem Advertising, 1990).

Al-Jazâ'iri, Jâbir, Aisar At-Tafâsî̀ li Kalâm al-'Aliy al-Kabîr, Vol. 1, (Jeddah: Racem Advertising, 1990)

al-Qârdlâwî, Yûsuf, Retrived 02/04/2018 from http:// www.qaradawi.net/site/topics/static.asp?cu_no=2\&ln g_id $=119$ \&temp_type $=42$

Arifin, Imron, Penelitian Kualitatif Dalam Ilmu-Ilmu Sosial dan Kegamaan (Malang: Kalimasahada, 1996).

Azra, Azyumardi, Jaringan Ulama, 27 dan 'Abd Allâh Salâmah Nashr, Al-Azhar al-Sharîf fî Dlaw' Sîrah A'lâmih al-Ajillâ' (Kairo: Maktabah Wahbah, 1996)

Baykan, Aysegul, "Perempuan antara Fundamentalisme dan Modernitas", in Bryan Turner, Teori-teori Sosiologi Modernitas Posmodernitas, terj. Imam Baehaqi dan Ahmad Baidhowi (Yogyakarta: Pustaka Pelajar, 2008)

Bungin, Burhan, Sosiologi Komunikasi: Teori, Paradigma, dan Diskursus Teknologi Komunikasi di Masyarakat (Jakarta: Prenada Media Group, 2008)

Dzul Faqqar 'Ali, Mu'jam al-Wasith, (Kairo: ZIB, 1973)

Furchan, Arief, Pengantar Metode Penelitian Kualitatif (Surabaya: Usaha Nasional, 1992)

Hariyanto, Erie. "GERBANG SALAM: Telaah Atas Pelaksanaanya Di Kabupaten Pamekasan." KARSA: Journal of Social and Islamic Culture 15, no. 1 (25 Maret 2012): 73-81.

Ibn Manzhûr, Lisân al-'Arab (Kairo: Dâr al-Ma'ârif, nd.)

Ibnu 'Asyur, Ushîl al-Nizhâm al-Ijtimấ '̂ fi al-Islâm, 1979) 
John Creswell, W, Research Design; Qualitative \& Quantitative Approach, (California; Sage Publications, 1994).

Khaled Abou El Fadl, Selamatkan Islam dari Moslem Puritan (Jakarta: Serambi, 2006)

Kumanto Sunarto, Pengantar Sosiologi, (Jakarta: Lembaga Penerbit Fakultas Ekonomi UI, 2004)

Lexy Moleong, Metodologi Penelitian Kualitatif (Bandung: Remaja Rosdakarya, 1990)

M.A. al-Najjâr, Mu'jam Alfâzh al-Qur'ân al-Karîm (Kairo: Majma' alLughah al-'Arabîyah, 1996).

Majd al-Dîn Abû al-Sa'âdât al-Mubârak Muhammad ibn al-Athîr alJazarî, Jâmi' al-Ushûl fî̀ Ahâdîth al-Rasûl (tk.: Maktabah alHilwânî, 1969)

Muhammad 'Imârah, Ma'rakah al-Musthalahât bayna al-Gharb wa alIslâm, Eds. II (Kairo: Nahdlah Mashrîyah, 2004).

Muhammad Thahir Ibnu 'Âsyûr, At-Tahrîr wa al-Tanwîr, (Tunis: alDar Tunisiyyah, 1984) Islâm, Tunis: As-Sharikah at-Tûnisiyyah li at-Tauzî́, 1979).

Muhammad Asfar (ed.), Islam Lunak Islam Radikal: Pesantren, Terorisme, dan Bom Bali (Surabaya: JP Press Surabaya, 2003)

Muhammad Fu'âd 'Abd al-Bâqî, al-Mu'jam al-Mufahras li Alfâzh alQur'ân al-Karîm (Kairo: Dâr al-Hadîth, 1364 H.)

Muhammad Rizieq, Hancurkan Liberalisme Tegakkan Syariat Islam, Jakarta Selatan: Suara Islam, 2011).

Nasution, Harun, Islam Rasional: Gagasan dan Pemikiran, Eds. IV (Bandung: Mizan, 1996)

Nur, Afrizal dan Lubis, Mukhlis, "Konsep Wasathiyyah dalam AlQur'an: Studi Komparatif antara Tafsir al-Tahrîr wa al-Tanwîr dan Aisar al-Tafâsîr", Jurnal An-Nur, Vol. 4, No. 2 (December, 2015)

Nur, Afrizal dan Lubis, Mukhlis, "Konsep Wasathiyyah dalam AlQur'an (Studi Komparatif antara Tafsir al-Tahrîr wa al-Tanwîr dan Aisar At-Tafâsîr)" dalam An-Nur, Vol. 4 No. 2, 2015 (ejournal. uin-suska. ac. id)

Rafi Saumi Rustian. Apa itu Media Sosial, Retrived 03/10/2017 from http:// www. unpas. ac. id/apa-itu-sosial-media/.

Rakhmat, Jalaluddin, Psikologi Komunikasi, (Bandung: Rosda, 2008) 
Rodani, H. Komunikasi dan Dakwah. (Jakarta: Azhikra, 2010), vol 1.

Rulli Nasrullah, Komunikasi Antarbudaya di Era Budaya Siber, (Jakarta: Kencana, 2012)

Sutrisno Hadi, Metodologi Research, Vol. I (Yogyakarta: Andi Offset, nd.).

Sya'bân 'Abd al-'Athî, et al., al-Mu'jam al-Wasîth (Kairo:Majma' alLughah al-'Arabîyah, 2004), 1031.

The Editors of Encyclopædia Britannica, "Puritanism", retrieved 12/04/2018 from http://www.britannica.com/ EBchecked/topic/484034/Puritanism

Werner J. Severin - James W. Tankard, Teori Komunikasi, (Jakarta: Kencana, 2007)

Wikipedia. Media Sosial, retrieved 03/10/2017 from http://id. wikipedia. org/wiki/Media_sosial

Winarno Surakhmad, Pengantar Penelitian Ilmiah Dasar Metoda Tehnik, (Jakarta: Tarsito, 1980)

Yûsuf al-Qard\}âwî, al-Khashâ'ish al-'Ammah li al-Islâm (Kairo: Maktabah Wahbah, 2001)

Yûsuf al-Qardlâwî, "al-Wasathiyyah wa al-I'tidâl", in Mu'tamar Wasathîyah: Mukhtârât min Fikr al-Wasathîyah: http://www.wasatia.org/wpcontent/uploads/2010/05/book.pdf

Yûsuf al-Qardlâwî, al-Syahwah al-Islâmîyah bayn al-Jumîd wa alTatharruf (Kairo: Dâr al-Shurûq, 1996) 